\title{
SOIL AND WATER CONSERVATION PRACTICES AMONG THE INDEPENDENT OIL PALM SMALLHOLDERS IN BETONG AND SARATOK, SARAWAK, MALAYSIA
}

\author{
MOHAMAD ARFAN JOHARI*; NAZIRAH CHE JAAFAR*; NUR HANANI MANSOR* \\ and KHAIRUMAN HASHIM*
}

\begin{abstract}
Soil and water conservation (SWC) practices which are included in the Good Agricultural Practices (GAP) for oil palm production are essential to be adopted by oil palm growers in order to maintain the quality of natural resources and adhere to the environmental conservation. At present, no scientific study has been carried out to indicate the level of knowledge and adoption of SWC among the independent oil palm smallholders (ISH). This study was aimed to evaluate the knowledge and current adoption of SWC among members of the Saratok Sustainable Oil Palm Growers Cooperative. The quantitative and qualitative research methods applied to evaluate the level of SWC knowledge and adoption by oil palm smallholders were based on the checklist in the Roundtable on Sustainable Palm Oil (RSPO) and Malaysian Sustainable Palm Oil (MSPO). The data collected were via in-situ observation and face-to-face interviews with respondents. The results of the study indicated that the level of smallholders' knowledge on SWC practices is high, however, the adoption level is still low. Recommendations based on the research affirmed that incentive/assistance scheme from the government is necessary to help and encourage ISH and the MSPO certification becomes mandatory for the cooperatives to ensure that the SWC is adopted by ISH for their long-term benefit.
\end{abstract}

Keywords: oil palm, environmental conservation, soil and water conservation practices, independent oil palm smallholder.

Received: 18 November 2019; Accepted: 5 April 2020; Published online: 22 September 2020.

\section{INTRODUCTION}

Oil palm development in South-east Asia is associated with positive and negative impacts, depending on how it contributes to the stakeholders and non-stakeholders. Indonesia and Malaysia are the countries that are active in the cultivation of oil palm in South-east Asia. Indonesia and Malaysia are the largest producers of palm oil with a production of 36 million tonnes and 21 million tonnes, respectively. Figure 1 shows that the total global production of palm oil for the year 2017 was 66.855 million tonnes (Index Mundi, 2017), covering a total planted area of 19.04 million hectares, i.e. $0.36 \%$ of world's agricultural land (Kushairi et al.,

\footnotetext{
Malaysian Palm Oil Board,

6 Persiaran Institusi, Bandar Baru Bangi,

43000 Kajang, Selangor, Malaysia.

E-mail: arfan@mpob.gov.my
}

2018). The oil palm industry also accounted for 5\% of Malaysia's exports and 36\% of the country's gross domestic product (GDP) in the agricultural sector (Department of Statistics, 2016; MATRADE, 2016). The contribution of palm oil exports increased to RM 77.85 billion in 2017 compared to RM 67.92 billion in 2016 (MPOB, 2017).

Development of palm oil industry is also associated with the negative impact such as deforestation, loss of biodiversity, degradation of peat lands, and the increase of greenhouse gases (Greenpeace, 2011; Gilbert, 2013). In terms of natural resources, soil and water are the primary resources that are directly used for growing oil palm, and it is crucial to be sustainably conserved by stakeholders, including independent oil palm smallholders (ISH). Soil and water conservation (SWC) adoption by farmers is being globally discussed among the experts and policy-makers. Awareness on necessary 
measures to mitigate degradation of natural resources due to human activities has led to the increased strictness of the related policies made by the policy-makers in order to minimise the impacts. In agricultural systems, there is always an active link between the uses of soil and water for food production which is impossible to stop since the demand is increasing following the human population trend. However, the degradation of natural resources can be minimised and controlled through the adoption of Good Agricultural Practices (GAP). In Africa, SWC is one of the essential agricultural activities that need to be taken into consideration because the soil is on the stack (Smaling et al., 1997).

Technically, the SWC practices have to be managed wisely with full consideration be given because these resources will be utilised and used for a long time, either for oil palm or other crops. According to Scherr and Yadav (1996), land degradation by the year 2020 may pose a severe threat to food production and rural livelihoods, particularly in developing countries especially in poor and densely populated areas. It is economically expensive to reclaim or to improve the soil once it is eroded by water or wind, physically degraded or chemically depleted. Stoops and Cheverry (1992) stated that we have to safeguard it for the future generation while obtaining the best benefit from it. For the oil palm industry, the stakeholders have established specific organisation at the international level in order to ensure that all supply chains related to the industries are responsible for the conservation efforts.

For example, in the year 2004, the not-forprofit association known as the Roundtable on Sustainable Palm Oil (RSPO) was established to develop and implement global standards for sustainable palm oil production. It brought together the seven stakeholders from the oil palm producers (plantation, organised smallholders and ISH), palm oil processors and traders, consumer goods manufacturers, retailers, bank and investors, the environmental conservation $\mathrm{NGO}$ and social or developmental NGO. In the year 2005, the RSPO had set the certification standards for the smallholders. Commitment to the GAP adoption is one of the compulsory requirements that need to be adopted, and the SWC is one of the criteria. In the oil palm plantation, SWC is essential to be adopted by producers in order to ensure that the soil and water in the plantation are consistently in good condition to get higher productivity. For the established plantation companies, it might not be a big issue to them because they have better capability compared to the smallholders that are commonly lack of consistency.

In order to facilitate the education and development programmes for the ISH, the Malaysian government established a smallholders' cooperative named Sustainable Oil Palm Growers Cooperative (KPSM). As of December 2018, there were 56 KPSM established throughout the country, and the Saratok's cooperative is the first in Sarawak registering $486 \mathrm{ISH}$ as members. The main objectives of the cooperative establishment are to group the ISH under one organisation that can empower them and at the same time, increase their productivity and income in a sustainable manner. Thus, it is essential to know the current status on the adoption of SWC as a part of GAP among the cooperative members. There is limited information on the current status of adoption of SWC among the oil palm smallholders. Thus, the potential constraint and driving factors that may affect the level of adoption of SWC are the main issues focused on this study.

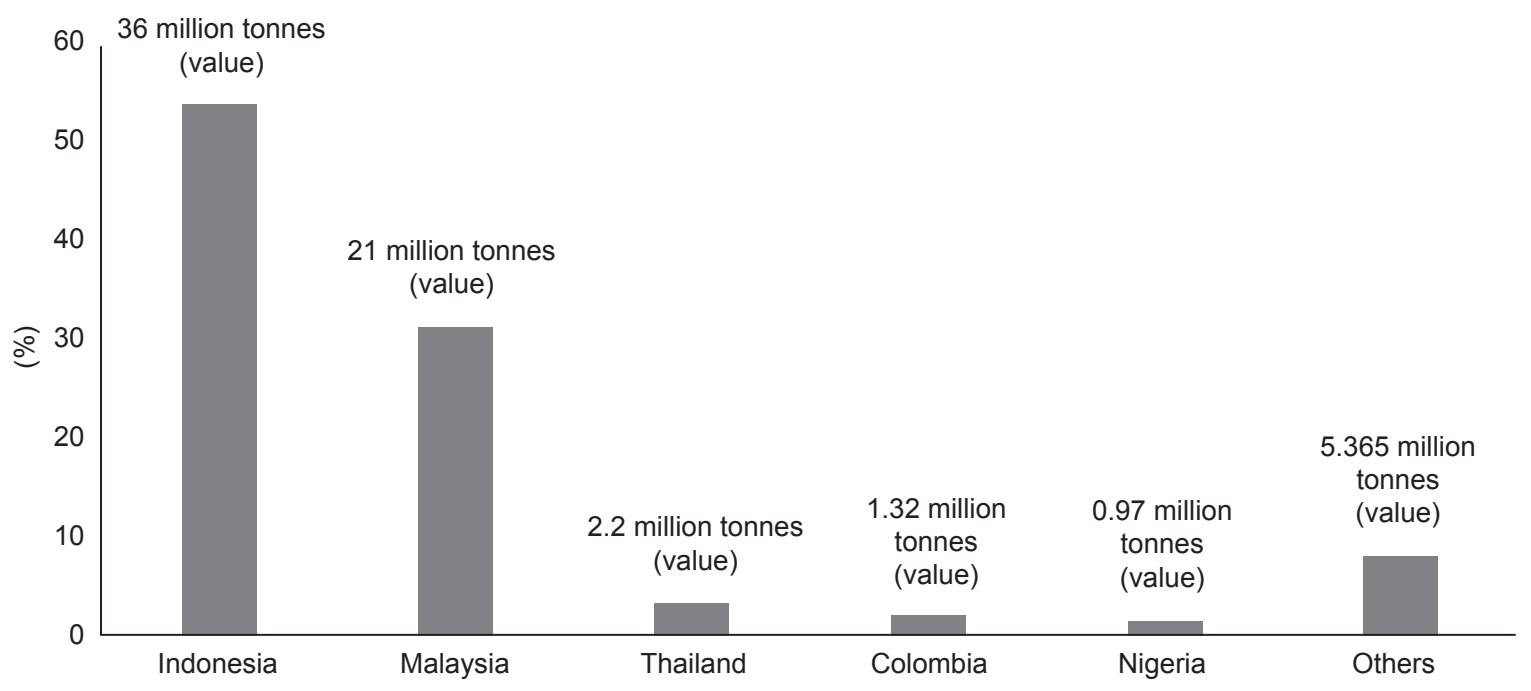

Source: Index Mundi (2017). 
Several studies have indicated various factors that influence on-farm adoption of soil conservation practices, including sociodemographic characteristics of farm operators and physical features of the farm. Physical and environmental characteristics such as farm size, slope length, the degree of slope, and soil erodibility also affect the adoption of conservation practices (Barbier, 1990). A study by Burton et al. (1999) indicates that farmer's age influences the adoption of new innovation other than education level. Economic and financial factors, such as farm and off-farm income and risk aversion, are found to influence adoption decisions (Featherstone and Barry, 1993). Farm income positively influences the adoption of technologies, while off-farm jobs inhibit this decision. Institutional factors such as land ownership, membership in farmers' organisations and technical assistance have been found in some studies to influence on-farm adoption of conservation practices (Francis, 1986). The insecurity of tenure reduces farmers' incentives to invest in the land conservation practices (Lee and William, 1983), while membership in local groups has a positive and significant effect on the adoption of such conservation technologies (Burton et al., 1999). Finally, perception of the erosion problem is found to be positively associated with the adoption of conservation practices (Santos et al., 2000). In Thailand, the necessary erosion protection and soil fertility measures are being adopted by the oil palm smallholders. They use a limited amount of chemicals for palm protection and fertilisation (Dalinger, 2011). In Malaysia, due to the lack of training and courses attended, SWC is the main factor that hinders the certification of GAP (Wahid et al., 2012). According to Rahman et al. (2008), the ISH in Malaysia are less efficient than other producers due to their smaller plot size, poor agricultural and data management practices. This is proven in a study conducted by Majid-Cooke et al. (2011) when a comparison was made using several different models of community involvement in the oil palm industry in Sabah and Sarawak. The ISH seem to perform better and effectively in terms of participation in the oil palm industry and financial performance compared to the government-led joint-ventures and schemes.

With no specific information on the current status and factors that may affect the adoption performance, it is quite difficult to plan a longterm strategy to overcome the problem. Available information on the previous report is more general and not specific to the smallholders in the oil palm sector. It is important to do the study of the real situation to get the real picture. This study was carried out to identify the level of knowledge and the current adoption of SWC practices in the smallholders' farms. The study was also to determine the relationship between the performances of SWC practices by ISH and their selected personal profile and farm background. This study also described and identified the potential driving and constraining factors that influence the level of SWC adoption among the ISH from the feedbacks given by them. The results of this study can provide information to relevant agencies on the status of knowledge and adoption level of SWC among the ISH, specifically the cooperative members.

\section{MATERIALS AND METHODS}

This study presented the data from a survey of 214 respondents from the ISH and randomly selected participants from 486 members of the Saratok's cooperative. The criteria for choosing the respondents consisted of: (i) contacting ISH through calls and visit; (ii) willingness to be interviewed and giving permission to visit their farm; (iii) ISH who planted oil palm on mineral and organic soils; (iv) ISH who planted oil palm on flat areas and hilly areas and (v) ISH who were able to answer the questions. The total number of sample size was determined according to the table of sample size created by Krejcie and Morgan (1970). The Saratok's cooperative operation area consists of two districts namely Betong and Saratok located in the state of Sarawak, Malaysia.

The data were collected using a specifically developed questionnaire. The questionnaire was developed via review of literature and criteria related to the soil and conservation knowledge and adoption by the community of farmers and oil palm growers. The criteria for soil and water conservation were created and referred to the MSPO Principle 5, Criteria 1 (environment management) and RSPO Principle 4 (use of GAP for estates and smallholders) Criteria 4.2, 4.3 and 4.4. The Criteria 4.2 and 4.3 consisted of the practices to maintain the quality and fertility of soil and control erosion and degradation. Criteria 4.4 consisted of the practices to maintain the quality and availability of water in the oil palm plantation. After completing the questionnaire, pre-test was carried out among the 30 cooperative members who were involved in this study. The data collection process took 10 months (July 2014 to May 2015) to be completed. To meet the purpose of the study, the questionnaire was divided into four parts, namely Parts A, B, C and D. Parts $\mathrm{A}$ and $\mathrm{B}$ consisted of the selected personal profiles and farm backgrounds of respondents. Part $C$ and $\mathrm{D}$ consisted of knowledge and adoption of soil and water conservation practices. The practices identified for determination of the knowledge and adoption levels of SWC by the ISH consisted of the RSPO Principle 4, Criteria number 4.2, 4.3, 4.4 and MSPO Principle 5, Criteria 1, and 2. Farm practices which were suggested to be adopted by ISH for soil quality 
and fertility maintenance included: (i) zero burning technique during land preparation; (ii) maintaining the soft grasses; (iii) proper front stacking for both hilly or flat areas; (iv) use of both chemical and organic fertilisers; (v) use of empty fruit bunches as mulching; (vi) leaving the biomass / crop waste at the farmland; (vii) establishment of legume cover crops or natural covers; and (viii) building of terraces or planting platforms at $4^{\circ}-25^{\circ}$ slopes. Whereas, the farm practices suggested to be adopted by ISH for water quality and availability maintenance included: (i) avoiding planting of oil palm at the buffer zone or road reserve; (ii) using of agrochemicals based on correct dosage; (iii) using of the optimum amount of fertiliser; (iv) avoiding fertiliser application in rainy season; (v) building of the silt pits; (vi) controlling the water level and (vii) proper front stacking technique for both flat or hilly areas.

Levels of respondents' knowledge towards SWC practices were identified through their level of agreement on the statements in the questionnaires. The respondents have five-scale of choices to determine their level of agreement for all the positive statement. Five-scale of the Likert Scale [i.e. (1) = strongly disagree; (2) disagree; (3) not sure; (4) agree; and (5) strongly agree] was fixed to facilitate the respondents in determining their agreement levels. The range from 1-5 giving the interval of 4 . For the study purpose, the knowledge of the respondents has been categorised into three levels (i.e. high-level, moderate-level and low-level). Thus, the interval (i.e. 4) was divided into three to get a class of interval of 1.33. Accordingly, the range for the categories of knowledge levels is as follows:

High level of knowledge: $3.67-5.00$

Moderate level of knowledge: $2.34-3.66$

Low level of knowledge: $1.00-2.33$

In Part D, data collection was assisted by farm visit by the extension officers to determine the level of adoption of SWC by the respondents. This was based on the scales of five as follows:

Scale 5: fully adopted $=$ SWC practices were fully adopted based on SWC standard and respondents have SWC documents as a guide.

Scale 4: adopted $=$ SWC practices were adopted but without SWC standard as a guide.

Scale 3: not fully adopted $=$ SWC practices were merely adopted within some areas but not throughout the farm, and not according to SWC standard as a guide.

Scale 2: unadopted = respondents have SWC standard as a guide but unadopted SWC.

Scale 1: unadopted $=$ respondents did not have any SWC standard for reference and unadopted SWC on their farm.
Determination of the mean score levels using the standard method was used to get the range of possible scores (in this case, 1-5) and divided by the number of categories to be established (low, moderate and high). The range equals to four (5 minus 1) is divided by three leading to the class of interval of 1.33. Accordingly, range for the categories of adoption level levels was as follows:

High level of adoption: $3.67-5.00$

Moderate level of adoption: $2.34-3.66$

Low level of adoption: $1.00-2.33$

These classes gave the opportunity to discuss the performance achieved by the respondents and further link them with their personal and farm profiles. To determine the relationship between the adoption levels of SWC as the dependent variable with the knowledge levels, personal profiles and farm profiles as the independent variable, the chisquare test of independence was utilised. The hypotheses for the relationship between the SWC adoption levels with personal profiles, farm profiles of respondents were as follow:

$\mathrm{H}_{0}$ : There was a significant relationship between SWC adoption with the respondent's personal profiles and farm backgrounds.

$\mathrm{H}_{1}$ : There has no significant relationship between SWC adoption with the respondent's personal and farm backgrounds.

For this study, the significant alpha $(\alpha)$ is set at 0.05 . Data were analysed using SPSS version 22 to get the mean score, frequency, percentage and the relationship between independent variables and dependent variable. Data collection was carried out via face to face interview and in situ field observation in the respondent's farm. The discussion of the study was mainly guided by quantitative data and supported by the previous study that is related to this topic.

\section{RESULTS AND DISCUSSION}

\section{Personal Profiles and Farm Backgrounds of Respondents}

Tables 1 and 2 shows the distribution of respondent's personal profile and farm backgrounds. The age of respondents was divided into three groups, i.e. group I (20-39 years old), group II (40-60 years old) and group III (> 60 years old). According to the percentage, group I consisted of $6.1 \%$; group II, $61.2 \%$; and group III, $32.70 \%$. The mean age of the respondents was 55.63 years old. The data showed that most of the ISH $(93.9 \%)$ were categorised in groups II and III. In terms of gender, 
$94.4 \%$ of respondents were males, and $5.6 \%$ were females. In terms of participation, $60.3 \%$ of the respondents were full-timers, and $39.7 \%$ were parttime smallholders. Based on the information given, some of the part-time smallholders are working either as government servants or in private sectors. This study revealed that most respondents, $84.5 \%$ attended formal education. A total of $13.6 \%$ of the respondents did not have any formal education. A total of 3.3\% having a diploma or degree, $42.1 \%$ attended secondary schools and $41.1 \%$ primary schools. For the household income, $50.5 \%$ of the respondents earned below RM 1500 per month, while $34.6 \%$ between RM 1501-RM 3500 and only $15 \%$ earned more than RM 3501. In terms of assistance from the government, 214 respondents or $45.3 \%$ received assistance from Smallholder New Planting Scheme (TBSPK), and $54.7 \%$ did not. In this scheme, smallholders are entitled to get quality seedlings, land preparation incentives and agriculture inputs. Time spent in the farm showed that $26.2 \%$ of the respondents spent 1-7 days/ month, $30.8 \%$ spent $8-14$ days / month, $29.4 \%$ spent $15-22$ days/month and $13.6 \%$ spent $23-30$ days/ month.

The results for farm backgrounds in Table 2 , shows that $44.9 \%$ of the respondents had immature palms, $54.2 \%$ mature palms and $0.9 \%$ old palms. The average farm size was 3.1 ha. Out of 214 respondents, $79.9 \%$ of them had farm size below 4 ha, $17.3 \%$ had 4.1-10 ha, and only 2.8\% had more than 10.1 ha. According to Boahene et al. (1999), farm size is the first and probably the most critical determinant of the adoption of agricultural technologies. It is because farm size can affect and in turn, be affected by the other factors influencing adoption.

As for land ownership, $79.9 \%$ of the respondents had farmland without titles or so-called Native Customary Right (NCR) while $20.1 \%$ had land titles. There were three types of soil where the respondents planted oil palm, which were mineral alluvial, mineral inland or organic soil. Out of 214 respondents, $27.6 \%$ planted oil palms on mineral alluvial, $33.6 \%$ planted on mineral inland, and $38.8 \%$ planted on organic or peat soil. For the topography of the land, there were also three categories, i.e. flat, undulating and hilly areas. Some of the farm practices were different, depending on land topography. The distance between the farm and home was also investigated. The results showed that more than $94.8 \%$ of the farms were near to ISH home with a distance of less than 5 $\mathrm{km}$. There were only $5.2 \%$ of respondents having farmland with a distance of more than $5 \mathrm{~km}$ from home.

TABLE 1. PERSONAL PROFILES OF RESPONDENTS

\begin{tabular}{|c|c|c|c|c|c|}
\hline Profiles & Categories & Frequency & $\%$ & Mean & SD \\
\hline \multicolumn{6}{|l|}{ Age group (yr) } \\
\hline I & 20-39 years old & 13 & 6.1 & 55.63 & 11.55 \\
\hline II & 40-60 years old & 131 & 61.2 & & \\
\hline III & $>60$ years old & 70 & 32.7 & & \\
\hline \multirow[t]{2}{*}{ Gender } & Male & 202 & 94.4 & & \\
\hline & Female & 12 & 5.6 & & \\
\hline \multirow{2}{*}{$\begin{array}{l}\text { Smallholder's participation } \\
\text { (refer to the main income job) }\end{array}$} & Full time & 129 & 60.3 & & \\
\hline & Part time & 85 & 39.7 & & \\
\hline \multirow[t]{4}{*}{ Education level } & Diploma/Degree & 7 & 3.3 & & \\
\hline & Secondary school & 90 & 42.1 & & \\
\hline & Primary school & 88 & 41.1 & & \\
\hline & School absentee & 29 & 13.6 & & \\
\hline \multirow[t]{3}{*}{ Monthly household income (RM) } & $<1500$ & 108 & 50.5 & 2109.95 & 1585.24 \\
\hline & $1501-3500$ & 74 & 34.6 & & \\
\hline & $>3500$ & 32 & 15.0 & & \\
\hline \multirow[t]{2}{*}{ MPOB scheme recipients } & Participant & 97 & 45.3 & & \\
\hline & Non-participant & 117 & 54.7 & & \\
\hline \multirow[t]{4}{*}{ Day spend at the farm } & $1-7$ days / month & 56 & 26.2 & & \\
\hline & 8-14 days/month & 66 & 30.8 & & \\
\hline & 15-22 days / month & 63 & 29.4 & & \\
\hline & 23-30 days/month & 29 & 13.6 & & \\
\hline
\end{tabular}


TABLE 2. FARM BACKGROUNDS OF RESPONDENTS

\begin{tabular}{|c|c|c|c|c|c|}
\hline Profiles & Categories & Frequency & $\%$ & Mean & SD \\
\hline \multirow[t]{3}{*}{ Oil palm age $(y r)$} & $<4$ (Immature palms) & 96 & 44.9 & 5.66 & 3.30 \\
\hline & 5-18 (Mature palms) & 116 & 54.2 & & \\
\hline & $>19$ (Old mature) & 2 & 0.9 & & \\
\hline \multirow[t]{3}{*}{ Farm size } & $<4$ ha & 171 & 79.9 & 3.13 & 4.73 \\
\hline & 4.1-10 ha & 37 & 17.3 & & \\
\hline & $>10.1$ ha & 6 & 2.8 & & \\
\hline \multirow[t]{2}{*}{ Land ownership } & Land title & 43 & 20.1 & & \\
\hline & No title/NCR land & 171 & 79.9 & & \\
\hline \multirow[t]{3}{*}{ Soil types } & Mineral alluvial soil & 59 & 27.6 & & \\
\hline & Mineral inland soil & 72 & 33.6 & & \\
\hline & Organic (Peat soil) & 83 & 38.8 & & \\
\hline \multirow[t]{3}{*}{ Land topography } & Flat & 141 & 65.9 & & \\
\hline & Undulating & 42 & 19.6 & & \\
\hline & Hilly & 31 & 14.5 & & \\
\hline \multirow[t]{4}{*}{ Distance from home to farm } & $<1.0 \mathrm{~km}$ & 76 & 35.5 & 2.26 & 2.98 \\
\hline & $1.1-5.0 \mathrm{~km}$ & 127 & 59.3 & & \\
\hline & $5.1-10.0 \mathrm{~km}$ & 9 & 4.2 & & \\
\hline & $>10.1 \mathrm{~km}$ & 2 & 0.9 & & \\
\hline
\end{tabular}

Note: NCR - native customary right.

\section{The Level of SWC Knowledge and Adoption among the Respondents}

The results on the level of knowledge and adoption of the SWC among the ISH is shown in Table 3. The mean score for the level of knowledge of the ISH on the soil management practices (SMP) recorded that majority, $58.0 \%$, of them had a high level of knowledge, $14.3 \%$ with moderate knowledge, and $27.7 \%$ were low. However, the level of adoption recorded that the majority with $52.8 \%$ had low adoption, $5.6 \%$ were moderate, and $41.6 \%$ with a high level of adoption. In terms of the high level of knowledge for each practice in the soil management practices (SMP), using of empty fruit bunches as mulching recorded the highest $(72.9 \%)$ and establishment of legume cover crops recorded as the lowest score $(43.9 \%)$. Although the level of knowledge of ISH in using EFB recorded the highest score, the adoption was recorded the lowest with $1.4 \%$ ISH performed the practice similar to the establishment of legume covers. High operation cost and the unavailability of the EFB were standard issues mentioned by ISH as the constraining factors. Other than that, the EFB transportation cost from palm oil mill to the ISH's farm, and the EFB distribution cost were also taken into consideration. Some of the respondents mentioned that the employed workers demanded RM 3.00 per palm for EFB's distribution. So, in every hectare, the ISH has to spend RM 408-RM 468, depending on the total number of palm stand per hectare and it is not affordable to them.
For the water management practices (WMP), $50.9 \%$ of respondents had high knowledge, $13.6 \%$ moderate and $35.5 \%$ low. However, in terms of applications, the majority of respondents, $62.1 \%$ did not adopt the practices, $7.5 \%$ moderately adopted and $30.4 \%$ highly adopted. Drain cleaning recorded that $65.0 \%$ of respondents had a high level of knowledge. On the need for the construction of silt pits, $48.1 \%$ of the respondents had low knowledge about it. The mean score for the adoption of WMP showed that $30.4 \%$ of the respondents were categorised as high adoption, $7.5 \%$ were moderate, and the majority, $62.1 \%$ were low. Farm waste management practice recorded a total of $55.6 \%$ respondents categorised in high adoption, and silt pit construction recorded low adoption among $96.7 \%$ of the respondents. Lack of exposure to WMP was identified as the factor for the vast majority of the respondents being categorised as low-level adopters of various of practices. The priority given to several practices especially those related to increase the oil palm productivity can also influence the decision of the respondents on whether or not to adopt the WMP. Financial constraint is the main reason why the respondents have to decide which practices need to be given priority.

For example, a farm road connecting to the main road was wholly constructed by them with minimum assistance from the government. Prices of agriculture inputs such as fertilisers and chemicals for weed control which kept on increasing and unstable palm oil prices in the global market were also identified as constraints to the ISH to increase their investment on the WMP. 
TABLE 3. THE LEVEL OF KNOWLEDGE AND ADOPTION OF THE SWC AMONG THE ISH

\begin{tabular}{|c|c|c|c|c|c|c|c|c|}
\hline \multirow{2}{*}{ Criteria } & \multirow{2}{*}{ Practices } & \multirow{2}{*}{$\begin{array}{l}\text { Performance } \\
\text { level }\end{array}$} & \multicolumn{2}{|c|}{ High } & \multicolumn{2}{|c|}{ Moderate } & \multicolumn{2}{|c|}{ Low } \\
\hline & & & Freq & $\%$ & Freq & $\%$ & Freq & $\%$ \\
\hline \multirow{20}{*}{$\begin{array}{l}\text { Soil management } \\
\text { practices (SMP) }\end{array}$} & \multirow[t]{2}{*}{ Practicing zero burning technique } & Knowledge & 126 & 58.9 & 27 & 12.6 & 61 & 28.5 \\
\hline & & Adoption & 151 & 70.6 & 13 & 6.1 & 50 & 23.4 \\
\hline & \multirow{2}{*}{$\begin{array}{l}\text { Maintained and managed the soft } \\
\text { grasses }\end{array}$} & Knowledge & 122 & 57.0 & 20 & 9.3 & 72 & 33.6 \\
\hline & & Adoption & 156 & 72.9 & 17 & 7.9 & 41 & 19.2 \\
\hline & \multirow{2}{*}{$\begin{array}{l}\text { Pruned frond stacked across the slope } \\
\text { at hilly area }\end{array}$} & Knowledge & 139 & 65.0 & 21 & 9.8 & 54 & 25.2 \\
\hline & & Adoption & 25 & 11.7 & 5 & 2.3 & 184 & 86.0 \\
\hline & \multirow[t]{2}{*}{ Using chemical and organic fertiliser } & Knowledge & 151 & 70.6 & 13 & 6.1 & 50 & 23.4 \\
\hline & & Adoption & 129 & 60.3 & 22 & 10.3 & 63 & 29.4 \\
\hline & \multirow{2}{*}{$\begin{array}{l}\text { Frond stacked alternate palm row at } \\
\text { flat area }\end{array}$} & Knowledge & 113 & 52.8 & 28 & 13.1 & 73 & 34.1 \\
\hline & & Adoption & 76 & 35.5 & 19 & 8.9 & 119 & 55.6 \\
\hline & \multirow{2}{*}{$\begin{array}{l}\text { Using of empty fruit bunches as a } \\
\text { mulching }\end{array}$} & Knowledge & 156 & 72.9 & 17 & 7.9 & 41 & 19.2 \\
\hline & & Adoption & 3 & 1.4 & 3 & 1.4 & 208 & 97.2 \\
\hline & \multirow{2}{*}{$\begin{array}{l}\text { Maintained the oil palm biomass at } \\
\text { the farmland }\end{array}$} & Knowledge & 107 & 50.0 & 49 & 22.9 & 58 & 27.1 \\
\hline & & Adoption & 209 & 97.7 & 5 & 2.3 & 0 & 0 \\
\hline & \multirow[t]{2}{*}{ Establishment of legume cover crops } & Knowledge & 94 & 43.9 & 51 & 23.8 & 69 & 32.2 \\
\hline & & Adoption & 3 & 1.4 & 6 & 2.8 & 205 & 95.8 \\
\hline & \multirow{2}{*}{$\begin{array}{l}\text { Maintained and managed the natural } \\
\text { covers }\end{array}$} & Knowledge & 122 & 57.0 & 31 & 14.5 & 61 & 28.5 \\
\hline & & Adoption & 116 & 54.2 & 29 & 13.6 & 69 & 32.2 \\
\hline & \multirow{2}{*}{$\begin{array}{l}\text { Built the planting platform or terrace } \\
\text { for the area }>6^{0}\end{array}$} & Knowledge & 110 & 51.4 & 50 & 23.4 & 54 & 25.2 \\
\hline & & Adoption & 20 & 9.3 & 0 & 0 & 194 & 90.7 \\
\hline \multirow{10}{*}{$\begin{array}{l}\text { Water management } \\
\text { practices }(\mathrm{WMP})\end{array}$} & \multirow{2}{*}{$\begin{array}{l}\text { Conserves the buffer zone from any } \\
\text { activities }\end{array}$} & Knowledge & 89 & 41.6 & 36 & 16.8 & 89 & 41.6 \\
\hline & & Adoption & 60 & 28.0 & 23 & 10.7 & 131 & 61.2 \\
\hline & \multirow[t]{2}{*}{ Built the silt pits } & Knowledge & 70 & 32.7 & 41 & 19.2 & 103 & 48.1 \\
\hline & & Adoption & 2 & 1.4 & 6 & 2.8 & 207 & 96.7 \\
\hline & \multirow[t]{2}{*}{ Water level management in the farm } & Knowledge & 126 & 58.9 & 27 & 12.6 & 61 & 28.5 \\
\hline & & Adoption & 38 & 17.8 & 16 & 7.5 & 160 & 74.8 \\
\hline & \multirow[t]{2}{*}{ Practised farm waste management } & Knowledge & 122 & 57.0 & 20 & 9.3 & 72 & 33.7 \\
\hline & & Adoption & 119 & 55.6 & 21 & 9.8 & 74 & 34.6 \\
\hline & \multirow[t]{2}{*}{ Drain desiltation and maintenance } & Knowledge & 139 & 65.0 & 21 & 9.8 & 54 & 25.2 \\
\hline & & Adoption & 104 & 48.6 & 16 & 7.5 & 94 & 43.9 \\
\hline \multirow[t]{2}{*}{ Mean score (SMP) } & & Knowledge & 124 & 58.0 & 31 & 14.3 & 59 & 27.7 \\
\hline & & Adoption & 89 & 41.6 & 12 & 5.6 & 113 & 52.8 \\
\hline \multirow[t]{2}{*}{ Mean score (WMP) } & & Knowledge & 109 & 50.9 & 29 & 13.6 & 76 & 35.5 \\
\hline & & Adoption & 65 & 30.4 & 16 & 7.5 & 133 & 62.1 \\
\hline \multirow[t]{2}{*}{ Mean score (SWC) } & & Knowledge & 119 & 55.6 & 30 & 14.0 & 65 & 30.4 \\
\hline & & Adoption & 81 & 37.9 & 13 & 6.1 & 120 & 56.1 \\
\hline
\end{tabular}

Note: SWC - soil and water conservation; ISH - independent oil palm smallholders.

The mean score for the overall practices in the SWC showed that the knowledge level of the respondents was high at $55.6 \%$, while $14.0 \%$ were moderate, and $30.4 \%$ considered low. In contrast, the adoption level of SWC shows that the majority of the respondents (i.e. 56.1\%) were categorised as low-level adoption, $6.1 \%$ moderate and only $37.9 \%$ of the respondents were considered as high-level of adoption.

Relationship between Level of Knowledge and Adoption of the SWC Practices and the ISH Personal Profiles and Farm Background

The chi-square test of independence was utilised to determine the relationship between the level of knowledge and adoption of the SWC practices and the ISH personal profiles and farm backgrounds (Table 4). There was a significant relationship between the knowledge level of SWC with education level, $X^{2}(6, N=214)$ 197.173, $\mathrm{p}<0.001$, participation as an ISH, $\mathrm{X}^{2}(2, \mathrm{~N}=214)$ 10.182, $\mathrm{p}<0.006$, and household income, $X^{2}(4, \mathrm{~N}=214)$ $33.781, p<0.001$. These results revealed that the education level, ISH's participation as oil palm smallholder and household income are statistically associated and have influence on the knowledge level of SWC. It is in line with the findings from the studies of Abdulai and Huffman (2005) and Schipman and Qaim (2010), who reported that education level and household income can be influencing factors to the level of knowledge and adoption among farmers practising sustainable agriculture and adopting innovation. 


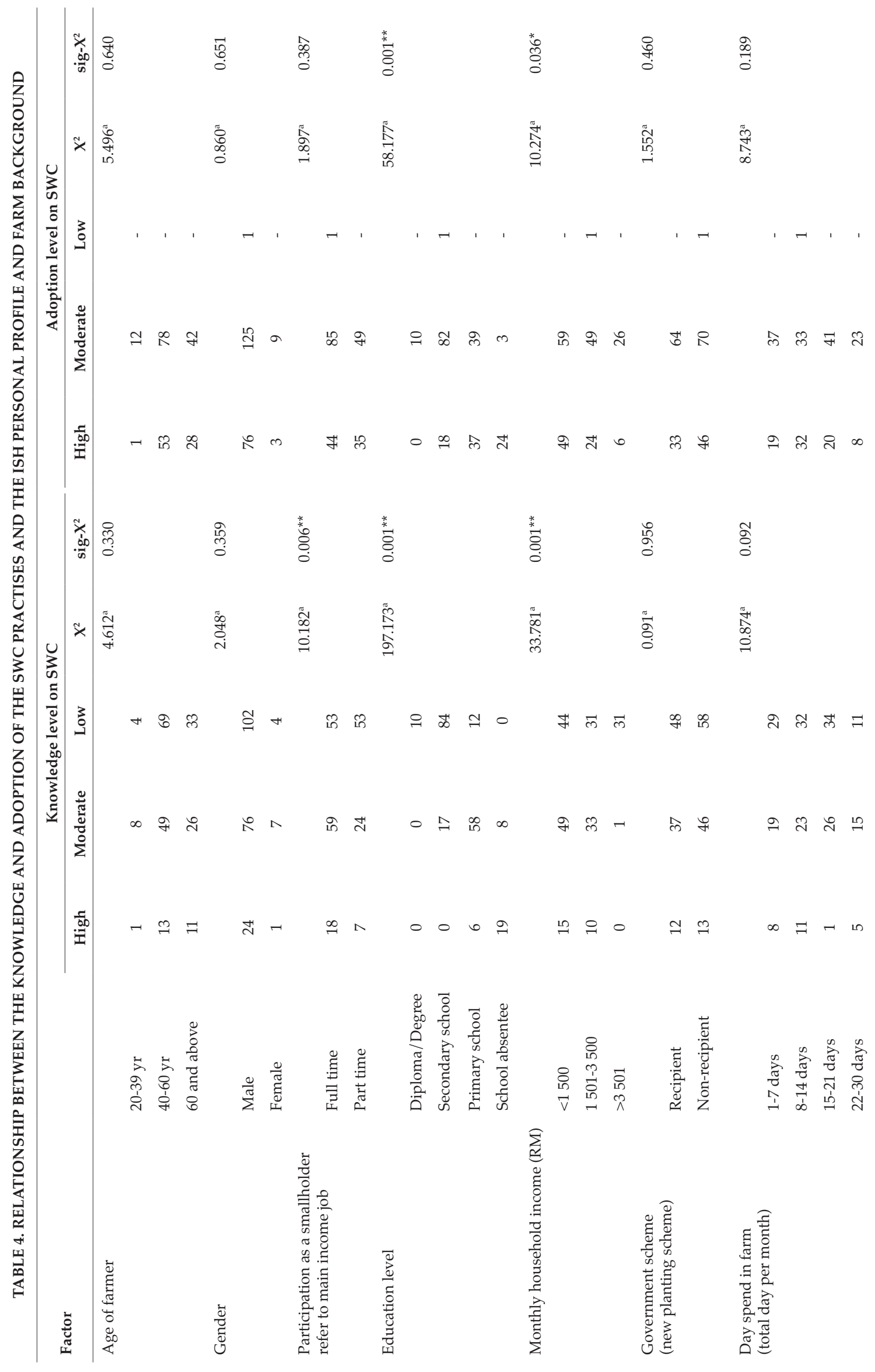




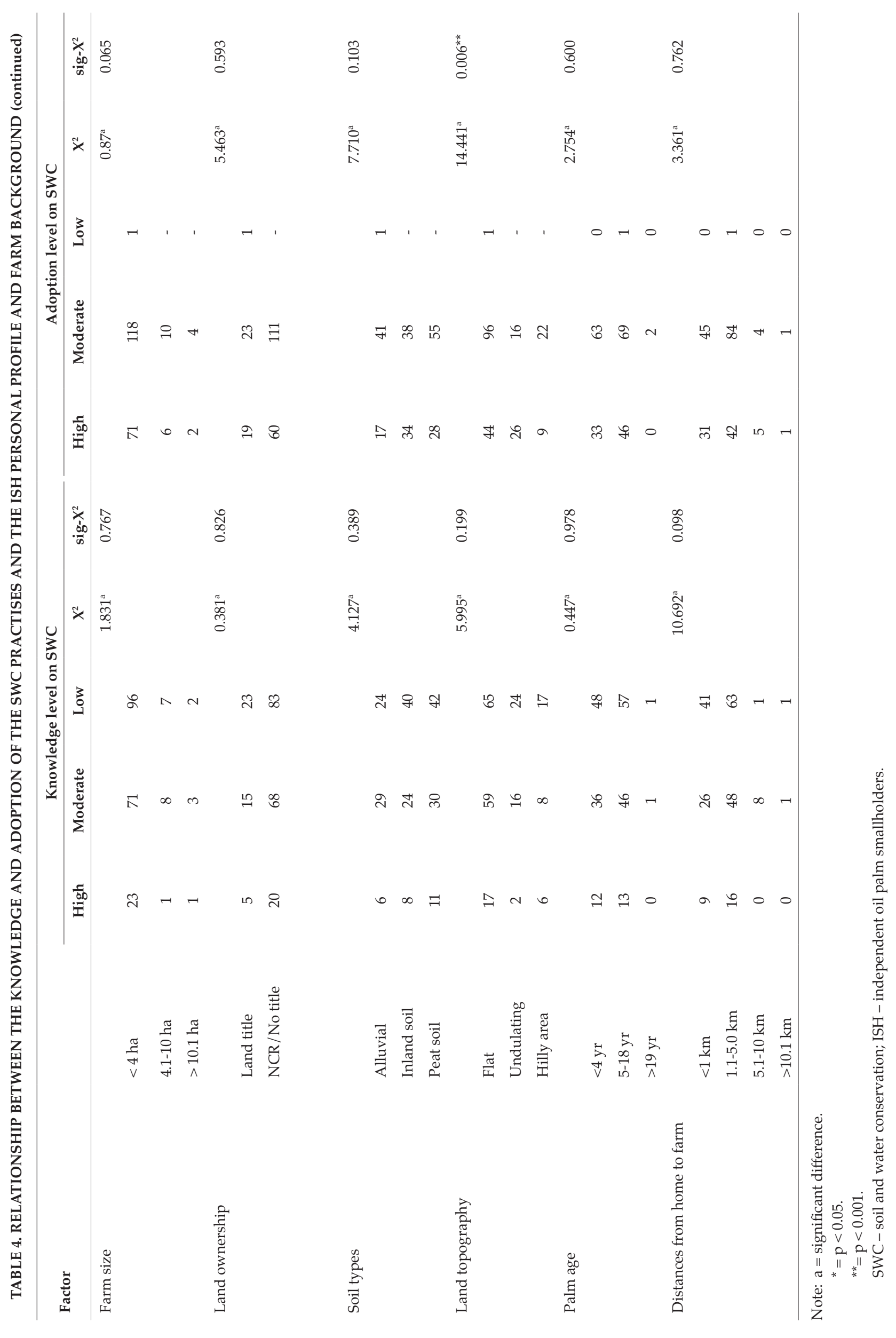


The significant relationship between the knowledge level of SWC with monthly household income shows that the respondents with high income were capable of recovering and willing to spend their money to get the information on innovations for their farm. Besides, although the respondents have the age constraint, with the high household income, they are capable of hiring workers to carry out the SWC practices that are physically challenging. According to Kim et al. (2012), household income has a positive and significant correlation to influence knowledge and acceptance of adaptation to climate change. Meanwhile, Gbetibouo (2009) explained that wealthy farmers are more interested in adapting to changing cultivation practices, use of irrigation and increasing the area of cultivated land. Furthermore, Hassan and Nhemachena (2007) reported that per capita income has a positive influence on the farmer's decision to take adaptation measures in maintenance.

In contrast, there was no significant relationship between the level of knowledge on SWC with age, $X^{2}$ $(4, \mathrm{~N}=214) 4.612, \mathrm{p}<0.33$, gender, $\mathrm{X}^{2}(2, \mathrm{~N}=214) 2.048$, $\mathrm{p}<0.359$, status of acceptance of assistance from the government, $\mathrm{X}^{2}(2, \mathrm{~N}=214) 0.091, \mathrm{p}<0.956$, the frequency of going to the farm, $X^{2}(6, N=214) 10.874$, $\mathrm{p}<0.092$, farm size, $X^{2}(4, N=214) 1.831, p<0.767$, land ownership, $X^{2}(2, N=214) 0.381, p<0.826$, soil types, $\mathrm{X}^{2}(4, \mathrm{~N}=214) 4.127, \mathrm{p}<0.389$, land topography, $\mathrm{X}^{2}(4$, $\mathrm{N}=214) 5.995, \mathrm{p}<0.199$, oil palm ages, $\mathrm{X}^{2}(4, \mathrm{~N}=214)$ $0.447, \mathrm{p}<0.978$, and the distance from the home to the farm, $X^{2}(6, N=214) 10.692, p<0.098$. The non significant relationship between the knowledge level with age of the farmer is similar to the finding of Siddiqui et al. (2006) who reported that age and awareness of the farmer to receive innovation has a negative correlation because of interest to get new information dwindles with age. The negative correlation between age and acceptance practices on farms is also in line with the study by Osuntogun et al. (1986).

In terms of the adoption level of SWC, results of the chi-square test revealed that there was a significant relationship between the adoption level of SWC with the education level, $X^{2}(6, N=214)$ 58.177, $\mathrm{p}<0.001$, monthly household income, $X^{2}$ (4, $\mathrm{N}=214) 10.274, \mathrm{p}<0.036$, and land topography, $\mathrm{X}^{2}(4$, $\mathrm{N}=214$ ) 14.441, $\mathrm{p}<0.006$. Results of the significant relationship between the adoption level of SWC with the education level, monthly household income and land topography are similar to those studies reported earlier (El-Osta and Morehart, 2002; Roger, 2003; Prokopy et al., 2008). Specifically, about breeding technologies, Khanal and Gillespie (2011) reported that in the US dairy sector specialised, more educated farmers are more likely to adopt advanced breeding technologies such as artificial insemination (AI), sexed semen and embryo transplants. According to Morrrison et al. (2007), most of the available evidence suggests that education is an important determinant of the decision to adopt new technologies, since it increases the ability of the individual to process relevant (new) information. In the oil palm smallholding sector, younger and educated ISH is more likely to adopt natural conservation practices such as conserving the soil natural covers, compared to elderly ISH who prefer blanket spraying for weed controls. Monthly household income for ISH was mainly obtained from FFB sales or off-farm income. For those respondents who totally depended on the income from the FFB sales, their puchasing power was potentially influenced by the FFB market price. Thus, if the FFB market price was low, then the monthly household income was also affected accordingly. It also affected the adoption level of farm practices that required ISH to spend in terms of financial capital, where the ISH have to delay for spending inputs for their farm.

However, there was non significant relationship between the adoption level of SWC with the age of ISH, $\mathrm{X}^{2}(4, \mathrm{~N}=214) 5.496, \mathrm{p}<0.640$, gender, $\mathrm{X}^{2}(2$, $\mathrm{N}=214)$ 0.860, ISH's participation as smallholder, $\mathrm{X}^{2}(2, \mathrm{~N}=214) 1.897, \mathrm{p}<0.387, \mathrm{p}<0.651$, status as the government scheme recipient, $X^{2}(2, N=214) 1.552$, $\mathrm{p}<0.460$, the total days in-farm working frequencies, $\mathrm{X} 2(6, \mathrm{~N}=214) 8.743, \mathrm{p}<0.189$, farm size, $\mathrm{X}^{2}(4, \mathrm{~N}=214)$ $0.87, \mathrm{p}<0.065$, land ownership, $X^{2}(2, N=214) 5.463$, $\mathrm{p}<0.593$, soil types, $\mathrm{X}^{2}(4, \mathrm{~N}=214) 7.710, \mathrm{p}<0.103$, oil palm ages, $X^{2}(4, N=214) 2.754, p<0.600$, and the distances from farm to home, $X^{2}(6, N=214) 3.361$, $\mathrm{p}<0.762$. According to Roger (1995) and Rubas (2004), there is no clear evidence about the effects of age that could affect the acceptance of innovation.

McNamara et al. (1991), Abara and Singh (1993), and Feder et al. (1985) had reported the relationship between the farm sizes with the adoption of the farm practices can be positive or negative. FernandezCornejo (1996) found a positive correlation between farm size and practice in the field. On the other hand, Yaron et al. (1992) and Harper et al. (1990) found a negative relationship between income and farm size. Although the farm size was small, the operating costs would impede the use of technology (Abara and Singh, 1993), especially if the technology requires substantial initial costs such as preparation of the work area with zero burning technique. Farmers have to pay rental costs of machinery and transport equipment to the farm. The cost of transporting machinery is the same despite the size of the farms. In this case, Feder et al. (1985) stated that only the more substantial plantation owner tried to use this type of innovation.

Several of SWC practices, such as building of terraces, construction of the drainage system and establishment of legume cover crops are one-off activities for the entire life cycle of the oil palm. Thus, the age of oil palm does not influence the adoption level of these practices. However, the growth 
performance of legume cover crops would decrease with oil palm age due to low light penetration because of closed oil palm canopy.

Regarding the relationship between the distance of the respondent's home to oil palm farm, the results showed there was no significant relationship between variables. It is because most of the respondent's farm was relatively close and with facilities in the farm to cater for their convenience. In some situations, the distances from the respondent's farm to home may affect the willingness of farmers to frequently visit the farm as they take into account the cost of transport, fuel and time constraint. A shorter distance from home to farmland makes it easier for ISH to monitor the farm-work carried out by employees more frequently.

\section{The Driving and Constraining Factors Faced by ISH in Order to Adopt SWC Practices}

Table 5 summarises responses by the respondents regarding the driving and constraining factors that could influence the adoption level of SWC. All the feedback mentioned by the respondents were converted into percentages for ease of interpretation. For the SMP, the most influential factor that drove the respondents to comply with SWC criteria were the returns of the practices to the land, capital and energy also known as profitability, followed by policy support and perceived attributes of innovation. In terms of constraining factors for SWC compliances, the outcome showed that the most influential factor was land suitability and followed by capital and credit availability.

For the returns of technology to the land, capital and energy, a total of $70.77 \%$ of the respondents mentioned that the adoption of the soil quality management could potentially minimise the production cost and increase income. For example, the application of EFB for mulching as the soil conditioner has been scientifically proven to be beneficial to maintain the fertility and quality of the soil. The respondents have to initially spend some extra financial capital to get the EFB from the palm oil mill and distribute them in their farms. Once applied, the EFB act as a mulch, reduce the weeding cost and hence the production cost. However, a total of $9.98 \%$ of the respondents mentioned that the returns of technology to the land, capital and energy did not influence their adoption of SWC practices.

A total of $18.32 \%$ of the respondents mentioned policy support from the government drove them to adopt the SWC practices through incentive provided for land preparation. Another 7.15\% and $3.75 \%$ of respondents stated the adoption of SWC practices was encouraged by perceived attributes of innovation as well as perception and values, respectively. It shows that capital and credit accessibility, information and extension services, and land suitability are not the driving factors to comply with SWC practices. It is related to the knowledge level of respondents where the majority of them have high level of knowledge and less dependent on extension officers for technology transfer.

Land suitability was identified as a constraining factor that influenced the soil quality management practices by respondents. A total of $43.04 \%$ of the respondents found the soil quality management practices as not suitable to the conditions of their land such as topography and soil types. There was no necessity for them to comply with that standard. For capital and credit accessibility, $25.41 \%$ of the respondents mentioned that the factor influenced them not to adopt the SMP practices. It was probably related to the requirement by the credit providers which were difficult to comply. For example, on matters pertaining to land ownership status. Some credit providers required a land document as a guarantee. However, based on information from the respondents, in the state of Sarawak almost $90 \%$ of ISH planted oil palm on land without ownership documents. In addition, the data showed that $8.70 \%$ and $7.35 \%$ of the respondents mentioned that they failed to adopt the practices due to limited

TABLE 5. FEEDBACK FROM RESPONDENTS ON THE DRIVING AND CONSTRAINT FACTORS FACED BY ISH TO ADOPT SWC IN THEIR FARM

\begin{tabular}{|c|c|c|c|c|c|c|c|c|c|c|c|c|c|c|}
\hline \multirow{3}{*}{$\begin{array}{l}\text { SWC technology } \\
\text { criterion }\end{array}$} & \multicolumn{14}{|c|}{ Driving (Drive) and constraining (Cont.) factors $(\%)$} \\
\hline & \multicolumn{2}{|c|}{$\begin{array}{l}\text { Return to the } \\
\text { land, capital } \\
\text { and energy }\end{array}$} & \multicolumn{2}{|c|}{$\begin{array}{l}\text { Perception and } \\
\text { values }\end{array}$} & \multicolumn{2}{|c|}{$\begin{array}{c}\text { Capital } \\
\text { and credit } \\
\text { availability }\end{array}$} & \multicolumn{2}{|c|}{$\begin{array}{c}\text { Perceived } \\
\text { attributes of } \\
\text { an innovation }\end{array}$} & \multicolumn{2}{|c|}{$\begin{array}{c}\text { Information } \\
\text { and extension } \\
\text { services }\end{array}$} & \multicolumn{2}{|c|}{ Policy support } & \multicolumn{2}{|c|}{$\begin{array}{c}\text { Land } \\
\text { suitability } \\
\text { (topography } \\
\text { and soil } \\
\text { types) }\end{array}$} \\
\hline & Drive & Cont. & Drive & Cont. & Drive & Cont. & Drive & Cont. & Drive & Cont. & Drive & Cont. & Drive & Cont. \\
\hline $\begin{array}{l}\text { Soil management } \\
\text { practices (SMP) }\end{array}$ & 70.77 & 9.98 & 3.75 & 5.51 & - & 25.41 & 7.15 & 7.35 & - & 8.70 & 18.32 & - & - & 43.04 \\
\hline $\begin{array}{l}\text { Water management } \\
\text { practices (WMP) }\end{array}$ & 75.50 & 14.87 & - & 3.59 & - & 21.25 & - & 12.08 & - & 31.74 & 24.50 & 1.73 & - & 14.74 \\
\hline Mean score (SWC) & 73.14 & 12.43 & 1.88 & 4.55 & - & 23.33 & 3.58 & 9.72 & - & 20.22 & 21.41 & 0.86 & - & 28.89 \\
\hline
\end{tabular}

Note: SWC - soil and water conservation; ISH - independent oil palm smallholders. 
information and extension services and perceived attributes of an innovation. Perception and values recorded a total of $5.51 \%$ of the respondents stated that they were not influenced by the factor in adopting the SWC practices.

For the quality and availability of water management requirements, only two driving factors were identified. Returns or benefit of the practices to the farmland were identified as the driving factors that encouraged the respondents to adopt SWC practices. Water management is much related to the quality and fertility of soil as well as to oil palm productivity.

With regard to capital and energy, they are the essential factors that need to be justified before the ISH could decide to adopt the SWC on their farm. Wrong justification may lead to the loss of both capital and energy that have been invested. Policy support where the government or others stakeholder's aid such as a grant from the government, credit facility from financial agencies in order to facilitate ISH to carry out the practices also seemed to be a driving factor.

Refer to the Table 5, a total of $75.50 \%$ of respondents mentioned that return or benefit of the technology to the land, capital and energy was the main constraining factor to the adoption level of water quality maintenance in SWC. In contrast, $14.87 \%$ stated that they were not affected by this factor to adopt SWC practices. In terms of policy support, $24.50 \%$ stated that policy support led them to adopt SWC practices, while $1.73 \%$ claimed this was a constraint for them to comply with that SWC. The information and extension services dominated the constraining factors in adopting the SWC practices, followed by capital and credit accessibility where a total of $24.50 \%$ respondents mentioned that this was a constraining factor for them to adopt SWC practices. In contrast, $21.25 \%$ of the respondents mentioned that capital and credit availability influenced the adoption level of SWC practices. Perceived attributes of innovation and perception and values recorded $12.08 \%$, and 3.59\% of the respondents, respectively. They mentioned that both these factors were the constraining factors for them to adopt SWC practices on water quality maintenance.

Results of the study revealed that the driving factor for both SWC criteria was the return or benefit of technology to land, capital and energy with $73.14 \%$ of the respondents agreed that this factor gave a significant impact for them in adopting SWC practices. This factor was followed by policy support and perceived attributes of innovation with $21.41 \%$ and $3.58 \%$ of the farmers to get SWC compliances. Therefore, in terms of constraining factors, the unsuitable practices introduced [compatibility of technology, Rogers (1995)] dominated with a total of $28.89 \%$.
Based on the results of the study, it is recommended that SWC incentive payment be given to the ISH whose farm has been certified in order to encourage others to also strive for certification. The integrated SWC training program should be organised for the members of cooperatives to educate and inform them about environmentalfriendly practices that will improve and increase their yield which will increase their income. Impact on the effectiveness of the training program can be evaluated through observation on the total number of smallholders who participate and implement the methods learned from the conducted trainings. Agricultural extension agents should intensify their efforts and focus in the dissemination of research information on techniques of soil and water conservation practices which are suitable for ISH as climate change adaptation techniques. Relevant government agencies are suggested to employ the competent and experienced extension officers in order to educate the ISH especially in Sarawak. The relevant agencies, such as MPOB, need to review their training programs for advisory officers, in order to ensure that they provide the officers with the skills needed to address farmers' needs. Training should be followed up and regularly reviewed to check on its relevance and up to date with the new agriculture technologies such as the use of precision agriculture and artificial intelligence.

In order to ensure a continuous supply of professionally trained people in agriculture, the relevant ministries and agencies should provide scholarship programs for students of agriculture and related sciences. Future studies on the factors that influence the adoption level of all practices related to natural resources conservation which involve ISH in the country could provide useful information for relevant agencies or ministries to plan strategies for improving conservation effort by ISH.

\section{CONCLUSION}

Based on the findings, it can be concluded that most of the smallholders (cooperative's members) are good in SWC knowledge but still lack on the adoption. Most of them do not practise SWC which is vital towards improving the soil and water quality in their farmlands and increasing their productivity. The study also found that there is a significant relationship between respondent's profiles (i.e. participation as a smallholder, education level and monthly household income) with the level of knowledge on SWC. Whereas, for the level of adoption the factors on education level, household monthly income and land topography have a significant relationship. Future studies need to focus on the driving and constraining factors 
that affect the adoption level of SWC and finding formulas to solve and overcome them. From this study, seven factors have been identified as driving and constraining factors: (i) return of the SWC innovation to the land, capital and energy, (ii) perception towards the SWC innovation and its values, (iii) capital and credit availability to perform the innovations, (iv) perceived attribute of the innovation, (v) information and extension services, (vi) policy support, and (vii) adaptability of the practices.

\section{ACKNOWLEDGEMENT}

The authors wish to thank the Director-General of MPOB for permission to conduct this project. The authors also wish to acknowledge all extension officers for their commitment and support throughout the whole process of this study.

\section{REFERENCES}

Abara, I O C and Singh, S (1993). Ethics and biases in technology adoption: The small farm argument. Technological Forecasting and Social Change, 43: 289300.

Abdulai, A and Huffman, W E (2005). The diffusion of new agricultural technologies: The case of crossbred-cow technology in Tanzania. America J. Agriculture Economy, 87: 645-659.

Barbier, B (1990). The farm-level economics of soil conservation: The uplands of Java. Land Economics, 66(2): 199-211.

Boahene, K; Snijders, T A B and Folmer, H (1999). An integrated socio-economic analysis of innovation adoption: The case of hybrid cocoa in Ghana. J. Policy Modeling, 21(2): 167-184.

Burton, M; Rigby, D and Trevor Young (1999). Analysis of the determinants of adoption of organic horticultural techniques in the United Kingdom. J. Agricultural Economics, 50(1): 47-63.

Dalinger, J (2011). Oil palm development in Thailand: Economic, social and environmental considerations. Oil Palm Expansion in South East Asia: Trends and Implications for Local Communities and Indigenous People (Colchester, $\mathrm{M}$ and Chao, $\mathrm{S}$ eds.). First edition. Forest People's Programme and Perkumpulan Sawit Watch. p. 24-51.

Department of Statistics Malaysia (2016). Monthly external trade statistics 2016. Department of Statistics Malaysia.
El-Osta, H S and Morehart, J (2002). Technology adoption and its impact on production performance of dairy operations. Review of Agricultural Economics, 22(2): 477-498. http:// dx.doi.org/10.1111/10587195.00034

Featherstone, A M and Barry, K G (1993). Factors influencing a farmer's decision to invest in longterm conservation improvements. Land Economics, 69(1): 67-81.

Feder, G; Just, R E and Zilberman, D (1985). Adoption of agricultural innovations in developing countries: A survey. Economic Development Culture Change, 33: 255-297.

Fernandez-Cornejo, J (1996). The microeconomic impact of IPM adoption: Theory and adoption. Agricultural and Resource Economics Review, 25(2): 149-160.

Francis, P A (1986). Land tenure system and the adoption of alley farming. Alley Farming in the Humid and Sub-humid Tropic (Kang, B T and Reynolds, L eds.). Proc. of an International Workshop. Ibadan, Nigeria. 10-14 March 1986.

Gilbert, D (2013). Rumble in the jungle. Earth Island J., 27(4): 40-45.

Greenpeace (2011). Deforestation for palm oil. http: / / www.greenpeace.org/ usa/en/campaigns / forests / forests-worldwide / paradiseforests / ourwork-in-paradise/, accessed on 4 April 2011.

Harper, J K; Rister, M E; Mjelde, J W; Drees, B M and Way, M O (1990). Factors influencing the adoption of insect management technology. Amer. J. Agric. Eco., 72(4): 997-1005.

Hassan, R and Nhemachena, C (2007). Micro-level analysis of farmers' adaptation to climate change in Southern Africa. International Food Policy Research Institute (IFPRI). IFPRI Discussion Paper, 714: 1-30.

Index Mundi (2017). Malaysia palm oil production by year. http:/ / www.indexmundi.com/agricultur $\mathrm{e} /$ ?country $=$ my\&commodity $=$ palmoil\&graph $=$ pro duction, accessed on 20 December 2019.

Khanal, A R and Gillespie, J M (2011). Adoption and profitability of breeding technologies on United States dairy farms. Southern Agricultural Economics Association Annual Meeting. Corpus Christi, Texas, USA. 5-8 February 2011.

Kim, C; Jung, H; Lee, S; Park, S and Takei, A (2012). An analysis on determinants of farmers' adaptation 
to climate change in Korea. J. Rural Development, 35 : 53-72.

Krejcie, R V and Morgan, D W (1970). Determining sample size for research activities. Educational and Psychological Measurement, 30(3): 607-610.

Kushairi, A; Loh, S K; Azman, I; Elina, H; Meilina, O A; Izuddin, Z B; Razmah, G; Shamala, S and Ahmad, P G K (2018). Oil palm economic performance in Malaysia and R\&D progress in 2017. J. Oil Palm Res. Vol. 30(2): 163-195.

Lee, L K and William, H S (1983). Land ownership and adoption of minimum tillage. Amer. J. Agric. Eco., 65(2): 256-264.

Majid-Cooke, F; Toh, S and Vaz, J (2011). Communityinvestor Business Models: Lessons from the Oil Palm Sector in East Malaysia. International Institute for Environment and Development, United Kingdom. p. 1-71.

Malaysia External Trade Development Corporation (MATRADE) (2016). Performance for the period of January-June 2016. http://www.matrade.gov. my/en/malaysia-trade-performance/3536-tradeperformance-june-2016-and-january-june, accessed on 28 February 2020.

McNamara, K T; Wetzstein, M E and Douce, G K (1991). Factors affecting peanut producer adoption of integrated pest management. Review of Agricultural Economics, 13: 129-139.

Morrison, A; Raju, D and Sinha, N (2007). Gender equality, poverty, and economic growth. Policy Research Working Paper 4349. The World Bank, Washington. 54 pp.

MPOB (2017). Overview of the Malaysian oil palm industry 2017. http://www.bepi.mpob.gov.my/ images / overview / Overview_of_industry_2017. pdf, accessed on 8 August 2019.

Osuntogun, A; Adeyemo, R and Anyanwu, E (1986). The adoption of innovation by cooperative farmers in Nigeria. Tropical Agriculture, 63(2): 158-160.

Prokopy, L S: Floress, K; Klotthor-Weinkauf, D and Baumgart-Getz, A (2008). Determinants of agricultural best management practice adoption: Evidence from the literature. J. Soil and Water Conservation, 3(5): 300-311.

Rahman, A K A; Abdullah, R; Shariff, F M and Simeh, M A (2008). The Malaysian palm oil supply chain: The role of the independent smallholder. Oil Palm Industry Economic J., 8(2): 17-27.
Rogers, E M (1995). Diffusion of Innovations. Fourth edition. The Free Press, New York. 518 pp.

Rogers, E M (2003). Diffusion of Innovations. Fifth edition. The Free Press, New York. 576 pp.

Rubas, D (2004). Technology Adoption: Who is Likely to Adopt and How does Timing Affect the Benefits? Ph.D thesis. Texas A\&M University. http://oaktrust. library.tamu.edu/bitstream/handle/1969.1/1252/ etd-tamu-2004B-AGEC-Rubas-2.pdf, accessed on 21 September 2019.

Santos, H; Thurow, A P and Thomas, L T (2000). Linkages between investment in extension services and farmers: Adoption of soil conservation practices in Southern Honduras. Technical Bulletin No. 200002. USAID-Soil Management CRSP. Texas A\&M University.

Scherr, S J and Yadav, S (1996). Land Degradation in the Developing World. Issues and Policy Option for 2020. International Food Policy Research Institute (IFPRI), Washington. 2 pp.

Schipmann, C and Qaim, M (2010). Spill overs from modern supply chains to traditional markets: Product innovation and adoption by smallholders. Agricultural Economics, 41: 361-371.

Siddiqui, B N; Muhammad, S and Malik, N H (2006). Effect of socio-economic aspects on the awareness and adoption of recommended horticultural practices by apple growers in Balochistan, Pakistan. Pakistan J. Agriculture Sciences, 43(1-2): 7376.

Smaling, E M A; Nandwa, S and Janssen, B H (1997). Soil fertility in Africa is at stake! Replenishing Soil Fertility in Africa (Buresh, R J; Sanchez, P A and Calhoun, F eds.). SSSA Special Publication No. 51. Madison, Wisconsin. p. 47-61.

Stoops, G and Cheverry, C (1992). New challenges for soil research in developing countries: A holistic approach. Proc. Workshop of the European Community, Life Science and Technologies for Developing Countries (STD 3 Programme). March 1992. Rennes, France. 22 pp.

Wahid, O; Nur Hanani, M and Nazirah, C J (2012). Pensijilan ladang sawit: Proses peningkatan produktiviti pekebun kecil. Prosiding Kebangsaan Pekebun Kecil Sawit 2012. MPOB, Bangi. p. 109-116.

Yaron, D; Dinar, A and Voet, H (1992). Innovations on family farms: The Nazareth region in Israel. Amer. J. Agric. Eco., 74(2): 361-371. DOI:10.2307/1242490. 